\title{
THE VALUES OF LOCAL WISDOM OF MINANGKABAU CULTURE IN A BARALEK GADANG TRADITIONAL WEDDING
}

\author{
Helzi Ramanta ${ }^{1 *}$; Samsuri² \\ 1,2 Postgraduate Program, Pancasila and Citizenship Education, Yogyakarta State University \\ Jl. Colombo Yogyakarta No. 1, Sleman, Daerah Istimewa Yogyakarta 55281, Indonesia \\ 'ejikramanta@gmail.com; 2samsuri@uny.ac.id
}

Received: 14 ${ }^{\text {th }}$ August 2020/ Revised: 24 $4^{\text {th }}$ August 2020/ Accepted: 07 ${ }^{\text {th }}$ September 2020

How to Cite: Ramanta, H., \& Samsuri. (2020). The values of local wisdom of Minangkabau culture in a Baralek Gadang traditional wedding. Humaniora, 11(3), 193-201.

https://doi.org/10.21512/humaniora.v11i3.6625

\begin{abstract}
The research aimed to (1) describe the traditional Minangkabau Baralek Gadang marriage; (2) analyze the procedures for the Minangkabau traditional wedding ceremony Baralek Gadang; (3) analyze the values of local wisdom in the traditional Minangkabau wedding Baralek Gadang. The research method applied was qualitative research, which was a literature study. Sources of data were books, journals, and internet sites related to the selected topic. The research data source consisted of books and journals about local wisdom of the Minangkabau culture in the customary marriage of Baralek Gadang. Data collection was carried out using documentation techniques, looking for data about things or variables in the form of notes, books, papers or articles, and journals. The data analysis technique used in the research was the content analysis method. The results show that (1) customary marriage in the Minangkabau community is identical with the existence of traditional ceremonies, which have many unique things and some rules that must be obeyed both based on customary provisions and Islamic teachings. The traditional wedding procession in Minangkabau custom has several conditions that must be carried out before getting married. (2) The procedures for the traditional Minangkabau Baralek Gadang wedding ceremony include the preparation for the wedding, the implementation of the wedding, and the implementation after the wedding ceremony. (3) The values of local wisdom contained in Minangkabau Baralek Gadang customary marriages include religious values, social values, knowledge values, language values, and artistic values.
\end{abstract}

Keywords: local wisdom, Minangkabau culture, Baralek Gadang, traditional wedding

\section{INTRODUCTION}

Globalization affects the shifting of local cultural values to global cultural values. This is due to the opening of extensive access to information, which causes a person to easily adopt values, knowledge, and habits that are different from their social environment. It should be understood that global values that are currently developing do not always bring good benefits to the development of local cultural value (Suwardani, 2015). However, globalization has a negative impact in the form of the erosion of the noble values of the nation's culture, which are then replaced by foreign cultures, which often conflict with the culture adopted by the Indonesian people. Globalization in the national context is a threat to an era in order to protect better and preserve local cultures so that their uniqueness can be maintained. For Indonesia, the inclusion of global values is a challenge for indigenous culture to maintain the uniqueness of local culture owned by various regions in this country (Alma, 2010). Therefore, efforts that can be made so that the existing cultural values do not fade. It can be maintained by implementing local wisdom to individuals and communities.

Local wisdom is defined as a local cultural wealth, which contains the meaning of virtue and a community viewpoint to implement cultural values in daily life. Local wisdom contained in Indonesia does not only apply locally to certain ethnicities but includes cross-cultural or cross-ethnic in various 
regions to form cultural values that are national in nature (Affandy, 2019). Local wisdom possessed by certain ethnic groups is obtained through community experiences passed down from generation to generation (Rahyono, 2009). This indicates that local wisdom is obtained through community experiences that are very strongly attached to cultural values within the community. Cultural values are possessed by an ethnic certainly for a long time and have existed throughout the existence of these communities.

Rasyidin in Makmur and Dastina (2018) has identified that local wisdom contained in a society or ethnicity consists of local wisdom in the form of philosophy; local wisdom in the form of social life attitudes, and suggestions expressed in the form of proverbs, parables, poetry or folk tales; local wisdom in the form of traditional ceremonies; local wisdom in the form of principles, norms, and rules that are evident in the social system; and local wisdom in the form of daily habits and behavior in social interactions. The existence of local wisdom in society is an asset and wealth of the nation that is of strategic value, importance, and of course, valuable and economical.

Minangkabau is an ethnic group in Indonesia that has uniqueness in its socio-cultural moral values that are contained in Minangkabau culture. Social moral values in the Minangkabau community are the Minangkabau tribe's identities, which are derived from the Minangkabau values, beliefs, and socio-cultural heritage that are used as references in behavior in everyday life (Hastuti \& Oswari, 2016). The core values of the Minangkabau community have been around for a long time and are compiled by traditional leaders. This core value is still upheld today by them, both those who live in West Sumatra and the Minangkabau people who live overseas. The values upheld by the Minangkabau people are known as adat nan sabana customs. It is the customs that are not subject to change, such as adat basandi syarak, syarak basandi kitabullah (customs based on Islamic law, Islamic law based on the Koran) (Firdaus et al., 2018).

One of the Minangkabau cultural values that are still upheld by the Minangkabau community is the Minangkabau traditional wedding tradition. Marriage in the Minangkabau traditional tradition, as stated by Asmaniar (2018), is one of the important events in the life cycle of each of the two parties of the extended family. It is a significant transitional period in forming a small group of new families to succeed the descendants. For Minangkabau men, marriage is a process to enter a new environment, namely the wife's family. Meanwhile, marriage for Minangkabau women is an addition to a new member of the family. The addition of the members in question is the join of Minangkabau men into Minangkabau women's families. Trimilanda and Desriyeni (2018) have stated that in the Minangkabau traditional wedding procession, the marriage is known as Baralek Gadang (big party). Baralek Gadang (big party) in Minangkabau custom consists of several stages that are commonly carried out by the Minangkabau community. This procession begins with the proposal, picks up the groom, and sits in the aisle. After the proposed procession is carried out, an agreement by both parties of the extended family to determine the wedding day will be carried out with the Minangkabau traditional procession and Islamic teachings.

Customary marriage in the Minangkabau community is believed to be the bond of relations between two large families, namely between male and female families. The phrase that is often expressed about marriage is indeed a pair of groom and bride (anak daro and marapulai), but those who marry are also two large families (Nofiardi, 2018). Customary marriage in the Minangkabau community is identical with the existence of traditional ceremonies that are very thick in it and have many unique things. There are some rules that must be obeyed, both based on customary provisions and according to Islamic teachings. The traditional wedding procession in Minangkabau custom consists of several conditions that must be carried out before the wedding is finally held. These requirements consist of the stage of marriage preparation, implementation of the wedding, and after marriage. This requirement must be carried out if they will hold a marriage ceremony. The goal is that customary meaning and cultural values contained in each procession are maintained and preserved, especially for future generations.

Based on the described exposure, this is why researchers are able to conduct in-depth research related to the values of local wisdom in Minangkabau traditional marriage. The research is important because it provides knowledge and understanding to readers in general related to Minangkabau culture. The research aims to describe the traditional marriage of Minangkabau Baralek Gadang and analyze the traditional marriage ordinances or processions of Minangkabau Baralek Gadang and local wisdom values contained in the traditional marriage of Minangkabau Baralek Gadang.

\section{METHODS}

The research applies a qualitative method with literature study style. According to Zed (2008), library study is a research activity related to collecting library data from various sources, such as books, articles, scientific papers, and journals, by reading, understanding, analyzing, and concluding the analysis results using theoretical studies. It is relevant to produce new findings in the form of descriptive data from various sources studied. In the research, sources of data are books, journals, and internet sites related to the local wisdom of Minangkabau culture in the customary Baralek Gadang wedding.

Data collection in the research is carried out with documentation techniques, which are looking for data about things or variables in the form of notes, books, papers or articles, journals, and others 
related to the local wisdom of Minangkabau culture in customary Baralek Gadang marriages. The data analysis technique used is the content analysis method. This analysis is used to obtain valid inferences and can be re-examined based on the context (Krippendorff, 2013). The stages in this analysis consist of the process of selecting, comparing, combining, and sorting various meanings so that relevant knowledge is found, supporting one another, and producing new findings related to the local wisdom of Minangkabau culture in the Baralek Gadang customary marriage.

\section{RESULTS AND DISCUSSIONS}

Marriage in the Minangkabau community is one of the most important and sacred events. Marriage in the life cycle of the Minangkabau community is a transitional period with the aim of forming a new family. For a Minang man, marriage is a process to enter a new environment, namely, into his wife's family. Meanwhile, marriage for Minangkabau woman is a process of adding new members to the rumah gadang. The marriage procession in the Minangkabau indigenous people is called Baralek Gadang (big party). It consists of several stages that are commonly carried out, starting from the procession of maminang (propose), manjapuik marapulai (picking up the bride), to basandiang (sit side by side at the aisle). After maminang and an agreement to determine the wedding day is obtained, the next procession in marriage is the implementation of traditional ceremonies and in accordance with the provisions of the Islamic teachings (Trimilanda \& Desriyeni, 2018). Baralek gadang (big party) in Minangkabau people generally lasts for two to three days based on customary agreements and provisions that must be carried out in order for the marriage to be considered valid (Hati, 2018).

Marriage in the Minangkabau is full of customary and religious meanings. The marriage that is carried out will form a new kinship in the tribe or clan who is married. The formation of a new family in these groups is not only about carrying out customary rules, but also in implementing Islamic religious rules, namely marriage (Sumardi, 2017). Amir (2011) has stated that the main requirements in Minangkabau traditional marriage are; first, each prospective bride and groom must be Muslim according to the main requirements of Minangkabau custom; second, each prospective bride and groom is not from a family that has the same blood or does not come from the same tribe; third, each prospective bride and groom has the attitude to be able to respect the parents and families of both parties; fourth, the prospective of bride and groom has a main job of income to ensure his/her life after marriage.

The regional cultural research and recording project of the Department of Education and Culture has added that the other main requirements for a Minangkabau man who wants to marry a Minangkabau woman are tando, dowry, and free money. Tando is giving something to the prospective bride as a sign of agreement between the two parties to bind a promise. Tando is given in the form of rings, bracelets, and other valuable objects. Meanwhile, the dowry is the prospective groom's obligation to give an amount of money to his future wife. The dowry amount is not determined but depends on the agreement between the prospective bride and groom. Uang jemputan or pick-up money or money lost is usually made in the Pariaman community. Uang jemputan is the amount of money or goods paid by the prospective bride to the groom before the marriage. The size and type have given depend on the agreement of both parties of the extended family (Janosik, 2005).

Asmaniar (2018) has stated that Minangkabau customary marriages are known as ideal marriages, larangan or prohibitions, pantang, and sumbang. First, the ideal marriage is a marriage between close family members. This close family marriage is a marriage between a child and a nephew, which is called 'rumah ka mamak' or 'baliak ka bako'. Marriage 'rumah ka mamak' means marrying the child of the father's brother, while marriage 'baliak ka bako' means marrying the father's nephew. This ideal is considered to be able to maintain and preserve the customary values in Minangkabau that have been passed down from generation to generation. Second, larangan or prohibited marriage is a marriage that is strictly prohibited based on the provisions of the Islamic religion. Prohibited marriage in Minangkabau custom is like marrying mother, father, children of a thousand and one siblings, brothers and sisters, brothers and sisters, parents-in-law and sons-in-law, wife and mother or step-father, sibling wife or husband, and son's siblings-dad man. Third, pantangan marriage is a marriage that will damage the customary system, such as having a marriage with a spouse who is still of the same ethnicity or tribe. Fourth, sumbang marriages are marriages that can destroy social harmony because they feel their dignity is no longer valuable. The form of sumbang marriage is like marrying someone who has been divorced by relatives, close neighbors, marrying a woman who is a relative or close, and marrying someone who is engaged.

Navis (1984) has added that various kinds of marriages occur in the Minangkabau community, such as, first, gantung marriages or marriages that are conducted but occur to couples who are not old enough, men do not have jobs or even women, and do not have sufficient funds to finance a wedding. Second is gulung tikar that applies to men or women of Minangkabau caused by their partner's death. This marriage is carried out so that the child from the previous marriage has parents who are not other people but those closest to them. Third is wakil (representative) marriage. It is a type of marriage widely practiced in the Minangkabau community because men cannot attend their weddings. Therefore, in exchange, the man could make a letter to represent himself to his father or brother to pronounce the marriage contract in his name in front 
of the penghulu. Fourth is cino buto marriage. It is a marriage that is carried out after a husband and wife have been divorced three times and are not allowed to reconcile so that the only way is for the woman to marry someone else first (which is called cino buto). Marriage is carried out based on the agreement that they will be divorced after the marriage contract; then, the woman can remarry her ex-husband.

The Minangkabau community truly value and uphold the customs and norms wherever they are. This is none other than because the meaning of a marriage bond in Minangkabau is so important that marriage becomes something that should be celebrated lively through traditional and religious ceremonies. According to the proverbial Minang, Adat Basandi Syarak, Syarak Basandi Kitabullah, the custom is based on Islamic religious law (Putra \& Iskandar, 2019). The importance of marriage in Minangkabau customs indicates that the Minangkabau traditional Baralek Gadang (big party) wedding procession has the meaning of merging and unifying two large groups (two families), which are different with their respective greatness, honor, dignity, and wealth (Elia, 2016). Based on that explanation, it is clear that the Baralek Gadang wedding in the Minangkabau tradition is not only a marriage carried out by the bride and groom, but it also involves two families who will unite into a large family of both parties of the bride and groom.

According to Hastuti and Oswari (2016), there are procedures for the Baralek Gadang customary wedding ceremony. The implementation procedure before the Minangkabau customary marriage, first is the initial stage or introduction stage. The initial stage in preparation for the Minangkabau customary marriage is called maresek. Maresek, as expressed by Ardillah (2019), is the first meeting in preparation for a Minangkabau customary marriage, which is held privately by each of the extended family. In this procession, the bride's family comes to the groom's family to discuss so that there is a marriage agreement. The discussion procession is carried out repeatedly so that the agreement desired by each extended family can be realized. After an agreement is reached, the next step is to determine a good day to hold the procession and exchanging signs (maminang and batuka tando). In this procession, generally, the bride's family brings souvenirs to the groom's family in the form of Minangkabau's typical food. A souvenir in Minangkabau custom is one of the characters that reflect courtesy when visiting people's homes. Therefore, souvenirs are an obligation that must be present in traditional events and have been carried out from generation to generation in Minangkabau customs.

The second is engagement. Engagement in the Minangkabau language is called maminang. Maminang in Minangkabau custom is when the bride's family comes to the groom's family to propose to him. If the marriage proposal is accepted, it will be followed by a procession of giving a binding sign between the bride and groom (batuka tando). This process in Minangkabau custom is interpreted as a symbol to bind the engagement promise. This agreement must not be terminated unilaterally by the bride or groom because it can tarnish the family's good name and the traditional leaders of each extended family. However, if one of them breaks the promise, there will be consequences of customary provisions that must be accepted. This procession is attended by the parents of the groom and bride as well as traditional leaders in the family (ninik mamak) of each extended family. As disclosed by Alif (2016), the procedures for implementing this procession are; first, the extended family of the bride comes to the groom's family with complete sirih or betel arranged in carano or kampla (a tool made of convex yellow metal that has a stalk). Second, the bride's family gives complete betel to the groom's family, where this stage is meaningful as hope in the meeting of each extended family. The meaning of hope, in this case, is that if there is an unwanted incident, then it will not become gossip in the future. If the meeting has a good meaning, it can be used as a good memory that will always be remembered by each extended family. Third, to include gifts brought by the bride's family in the form of cakes and fruits. Fourth, the bride's family begins this stage by serving betel to the groom's family to be tasted as a sign of the start of the procession. Fifth, the customary leader (ninik mamak) from the family of the bride and groom gives pantun (Indonesian verse consisting of four lines rhyming a-b-a-b of which the first two present a figurative suggestion of what is more directly and clearly stated in the final lines) to each other (sambah mengambah). Sambah menyambah in Minangkabau custom conveys the intentions and goals of the bride's family to propose to the groom. Pantun expressed from the bride's family will be replied to by the groom's family. In the Minangkabau tradition, sambah menyambah, in general, is an obligation that must exist in traditional events. Sixth, one of the spokespersons of the bride's family formally expresses the marriage proposal. Seventh, the procession of exchanging objects is the signs of engagement. The objects that are exchanged in this procession can be in the form of keris, traditional cloth, or other objects with historical value in the family. The items exchanged are temporary, which is only a symbol of binding promises and will be returned after the marriage procession.

The third is escorting the groom and future bride. Escorting the groom and the bride to the homes of the father and mother's relatives aims to give happy news about the wedding plans and ask for blessings from the relatives of the father and mother. When the groom wants to visit his father's and mother's relatives, the groom-to-be brings a package of leaves containing tobacco or cigarettes. Meanwhile, for the bride-tobe, when she wants to visit her mother's and father's relatives, she brings sirih lengkap. The inherent meaning of the groom and bride is a symbol of giving happy news to the relatives of the father and mother, respectively. Usually, in this procession, the family who is visited by both the father's and the mother's 
family will provide assistance in the form of cash. This assistance is given as a form of responsibility and affection for an uncle or aunt to his/her nephew, who is getting married. The amount of cash given is adjusted to the agreement and giving of each family, both from the father's side and from the mother's side.

The fourth is an event organized by the father's family for the bride-to-be. In Minangkabau, this event is called babako babaki. Babako babaki is defined as the life of working together in helping the bride and groom's wedding expenses. The amount of which is adjusted to the capacity of each of the father's family. This event is held before the marriage contract ceremony. Assistance can be given in the form of some cash, some gold, and items needed by the bride and groom for the wedding procession, such as a set of clothes and cooked side dishes and cakes. The implementation consists of some stages. First, the bride-to-be is picked up by the father's family to be brought to her father's family house. Second, when she arrives at her father's relative's house, the brideto-be sits down with her father's siblings to have some advice. The advice given is in the form of obligations and about the responsibilities that the bride will have when she is married. The advice given is always to maintain the good name of the extended family from the mother and the father's side, look after herself, maintain good relations with her father and biological mother, siblings, and good relations with the family of groom-to-be, both with in-laws and with brother in law. Advice is a form of reminder for the bride and groom to have an attitude of love and support for each extended family without distinguishing one another. Third, the next day, the bride-to-be is brought home by the father's family and is followed by bringing various items assisted by the father's family. These items are carried by using trays or typical trays of Minangkabau. The amount of which is in accordance with the assistance given by the father's family.

The fifth is malam bainai. Malam bainai is defined as the night to put a fine collision of daun inai or henna leaves onto the bride-to-be's nails. Malam bainai is defined as the bridal shower and the night of affection for both parents. Malam bainai has the purpose of informing the public that the bride-to-be is not a girl anymore but is ready to become a wife. The clothes used by the bride are traditional Minangkabau clothes with low suntiang. The equipment used in this procession is holy water containing seven forms of flowers, umbrellas, and yellow kain jajakan. The procedures for this procession are: first, the bride-tobe leaves the room and heads to the aisle to ask for blessing and apologize to both parents. Apologies and prayers are conveyed alternately from father to mother as a form of gratitude for being born, raised, educated, and guided during her lifetime. Second, the bride-to-be is led by both parents to step on the yellow cloth that has been laid out in front of the aisle. The cloth that stepped on by the bride-to-be means that the task of both parents in looking after and caring for their daughter has been completed. Third, the brother of the bride-to-be folds the yellow cloth that the bride has stepped on. This folding has the meaning of completing the brother's task in looking after his sister. Fourth is the procession of placing henna onto the nails of the bride-to-be. It is carried out by the father and mother first and then continued by the father and mother's closest relatives. Furthermore, Sylvia, Syahrel, and Marzam (2014) have stated that the process of putting henna on the bride's finger has different meanings on each finger. Thumb symbolizes the appreciation, kindness, and praise of the wife-tobe to her future husband; index finger symbolizes the future wife's caution in acting, not being arbitrary in her attitude, and not being free to rule; middle finger symbolizes caution in understanding the future parents-in-law, future brother and sisters-in-law, and other people; ring finger symbolizes the idealism of the couple in carrying out their married life; and little finger symbolizes the hope that the children they will have can behave good, humble, and not arrogant.

Sixth is picking up the groom-to-be. Picking up the groom in the Minang language is called manjapuik marapulai. The bride's extended family picks up the groom-to-be as a sign that the marriage contract procession will be held at the bride's house. The procedures for implementing this procession are; first, the extended family of the bride-to-be arrives at the groom's house with gifts on their hands, namely rice, Minangkabau chicken singgang (grilled chicken), side dishes, cakes, and fruits that have become a tradition in Minangkabau customs. Second, the bride's family delivers souvenirs to the groom's family. Third, one of the spokespersons of the bride conveys the intent and purpose of their arrival. Fourth, the groom is given a title as a sign of his maturity, which is ready to enter the gates of married life. The granting of titles is generally carried out as datuk or sutan. Of course, the awarding of this title is based on the level in the bride's family. Fifth, the groom-to-be is brought to the bride-to-be house along with the bride's extended family.

Seventh is welcoming the groom-to-be at the house of his future wife. Welcoming the groom to the bride's house is a very lively Minangkabau traditional wedding procession. The procedures for this procession are; first, when the groom has arrived at the bride's house, the groom is led (paraded) together with his extended family to meet the bride's extended family. Second, the reception is accompanied by typical Minangkabau music and silat done by youths who participated in enlivening the welcoming ceremony. Third, the groom-to-be is presented with betel, yellow rice, and white cloth, which indicates that a series of welcoming activities has been carried out by the bride's family to unite the bride in the groom's family line. Fourth, walking into the bride's house uses a Minangkabau umbrella while throwing yellow rice at the bride accompanied by the Minangkabau dance and music. Fifth, before the groom enters the house, the groom's feet are sprinkled with water first and then proceed by guiding him to walk on a white cloth to where the contract occurs. This procession is a 
form of purifying the groom-to-be before the sacred procession is carried out.

According to Hastuti and Oswari (2016), the procedures for the implementation before the Minangkabau customary marriage include; first is the marriage ceremony. The marriage ceremony begins with the Holy Quran's recitation, followed by a procession of consent granted. If the kabul consent procession is declared valid by witnesses, then proceed with prayers and reading each of the bride and groom's rights and obligations. The next procession is the seserahan handover from the groom to the bride. After the handover is complete, the bride's family will say a welcome reception. Those who represent this acceptance speech are usually the ninik mamak (traditional leader) of the bride. After the handover procession is complete, the procession is continued with a sungkeman procession to each of the two parents of the groom and the bride. Sungkeman is a form of apology and a token of devotion to the groom and bride to each of the two parents for the struggle and efforts that have been given in raising them since they were born until delivering them to the gate of marriage.

The second is the recitation. In general, recitation in the Minangkabau tradition is carried out after the marriage ceremony procession has been done. This recitation is an obligation that must be carried out by the elders of the Minangkabau traditional village because this has become a tradition in the Minangkabau community. The recitation is in the form of a religious lecture that has the following objectives; first is to pray for the groom and bride to become a married couple who are sakinah, mawadah, warrahmah, and eternal in this world and the hereafter. Second is praying for the groom and bride to always give attention and affection to each parent when they are married. The form of attention and affection must be fair and balanced between father and biological mother and father and mother-in-law. The third is praying for the families of each groom and bride who have fused into an extended family. It hopes that in the future, each of the two families can strengthen the sense of brotherhood and kinship without differentiating between siblings and in-laws. Fourth is praying for the groom and brideto-be blessed with lawful sustenance and have pious offspring so that they can become a source of reward for their parents in the future. After the religious lecture is finished, the procession is continued with a closing prayer. After the prayer reading is finished and shaking hands with the guests who are attended the event, the procession is continued with a procession of sit side-by-side for the groom and bride in the aisle. Sit down side-by-side in the aisle in Minangkabau custom is usually not required to be held on the same day, but can be carried out on the day after the marriage ceremony is held. This procession depends on the agreement of both parties of the family.

The third is sitting down side-by-side in the aisle for the bride and groom. Side by side in the aisle in Minangkabau custom is called a big party (Baralek
Gadang). Baralek Gadang is the culmination of the entire series in Minangkabau wedding customs. It is held as a form of gratitude and happiness from both parents because their child is married. This party is attended by each groom and bride's extended family, neighbors, close friends, relatives, and various invited guests who also prayed for the groom and bride. The groom and bride sit down side by side for a day in the aisle and serve the invited guests who attend. The clothes worn by the groom and the bride are the Minangkabau traditional greatness for the groom and the long brackets complete with suanting-shaped headdresses on the bride (anak daro) (Elia, 2016). Baralek Gadang is a significant procession in the Minangkabau tradition because of the timbang tarimo procession. According to Tanjung (2017), timbang tarimo, as expressed, is the customary handover of the groom to the family of the bride, who will then live with the extended family of the bride. This procession involves the role of the ninik mamak (traditional leader) from both sides. It is a form of completion of the obligations and responsibilities of the ninik mamak on the part of the groom in looking after and caring for his brother (nephew) before marriage and after marriage. In addition, for ninik mamak, the obligation and responsibility in looking after the groom have shifted to the responsibility of the ninik mamak (traditional leader) of the bride. If one day, a problem arises as a result of the groom's actions, the part that has the right to resolve the problem is the ninik mamak (traditional leader) of the bride. Meanwhile, the groom's ninik mamak (traditional leader) can intervene if the bride's ninik mamak (traditional leader) asks for help to solve the problem. After the timbang tarimo procession is carried out, the groom is legally a member of the bride's family home, whose position is a semenda (urang sumando) or an honoured guest in the family.

After the Baralek Gadang customary marriage, the groom lives in the bride's house. The groom's position is not as head of the family in the wife's house, but only as sumando (honored guest). Therefore, after marriage, Minangkabau men have two places to live, namely in his own house and at his wife's house (Sitompul, 2017). The next day, it will be continued with the last traditional procession, namely the manjalang. Manjalang is a procession that aims to introduce the bride to the groom's family to strengthen relations and get to know each other's extended family. In this procession, the bride's extended family brings juadah (food) to the groom's family. The kind and amount of food are determined based on customary provisions agreed upon by each party of the extended family. The juadah (food) brought by the bride's family is then taken by the groom's family to be served on plates during the event. This juadah is not taken entirely by the groom's family, but only half of the portion brought. The remaining results of the jaudah will later be brought back by the bride's family to be shared or eaten with the bride's extended family. After that, the procession is continued by entertaining the bride's family with a heavy meal consisting of 
rice, side dishes, fruits, and other typical food of Minangkabau (Gustin, Baidar, \& Elida, 2016).

The values of local wisdom in the Minangkabau community are not only obtained from the family environment but also through a custom inherited from the ancestors that have been passed down from generation to generation. One of the Minangkabau customs that are still upheld by the values of local wisdom, one of which is customary marriage. Minangkabau traditional weddings have specialty and uniqueness in each process. The specialty and uniqueness of this Minangkabau traditional wedding is rich in cultural elements. Koentjaraningrat (1990) has stated that cultural elements that are universally recognized by society consist of seven elements: the religious system, the social system, the knowledge system, language, and the arts. The five elements of culture in Minangkabau traditional marriage will be explained in detail.

First is the religious values. Minangkabau customary marriage is inseparable from religious elements or the Minangkabau people's beliefs, which are based on Islamic teachings. The traditional wedding procession in the Minangkabau community is an expression of gratitude to God Almighty. In addition to expressions of gratitude, the Minangkabau customary marriage of Baralek Gadang is also followed by praying to God Almighty to achieve salvation. Prayers are offered to instill the attitude of always remembering the creator. Belief in God as the owner of the universe shows one's faith. The Minangkabau traditional wedding procession, which contains religious values, is found in the procession of the implementation of the marriage ceremony and recitation. The procession of the marriage contract begins with the Holy Quran's recitation, which describes that before a sacred event is carried out, it must be preceded by prayers as a form of the request to Allah SWT so that the event can run well and convenient. Meanwhile, the religious value contained in the recitation procession is a form of gratitude for the bride and groom for the marriage. Recitation in the form of religious lectures has the aim of praying for the groom and the bride to become a married couple who are sakinah, mawadah, and warrahmah, and will last forever in this world and the hereafter. In addition, recitation aims to pray for the groom and bride always to give attention and affection to their parents when they are married.

The second is social value. The procession of Minangkabau customary marriage, Baralek Gadang, is full of social activities, such as responsibilities, deliberations, and mutual cooperation. Social value refers to the relationship between individuals in a community group. The value of the responsibility in Minangkabau traditional marriage lies in the procession of wedding preparation and the wedding's implementation. One of the preparations for the wedding procession is malam bainai. The value of the responsibility in the malam bainai procession is the completion of both parents' responsibilities in raising, educating, and guiding the prospective bride during her life. Meanwhile, in the marriage procession, the value of the responsibility contained is sit down side by side in the aisle for the bride and groom. Sit down side by side in the aisle is a sign of the traditional delivery of the groom to the bride's family, who will then live together with the extended family of the bride's family. This submission is a form of completing the duties and responsibilities of the ninik mamak on the part of the groom in looking after and caring for his brother (nephew) before marriage. Therefore, after marriage, the obligations and responsibilities in looking after the groom have shifted to the ninik mamak (traditional leader) of the bride. In this case, the value of mutual cooperation is significant for the survival of the community.

The value of mutual cooperation in society can create a safe and peaceful life. These values become a unity, as a form of cooperation which then creates solidarity within the community. The value of mutual cooperation in traditional Minangkabau Baralek Gadang marriage lies in the wedding preparation procession when delivering the groom-to-be and bride to the father's family from the bride's side and events organized by the father's family for the bride-to-be (babako babaki). In this procession, the value of mutual cooperation can be seen from the form of assistance provided by the father's family of the bride to help with the costs of the wedding. Assistance provided from the father's family is usually in the form of some cash, some gold, and items needed by the bride for the wedding procession such as a set of clothes, cooked side dishes, and other cakes. Meanwhile, the value of deliberations at the Minangkabau Baralek Gadang customary marriage procession can be seen in the initial assessment procession and exchanging signs between bride and groom as the symbol that they are engaged. The role of ninik mamak in this procession is prioritized in discussing plans that will be carried out after each extended family's agreement is reached. In this procession, the role of ninik mamak is an intermediary between two extended families to reach an agreement on marriage to be carried out from each extended family.

The third is the knowledge value. From the aspect of knowledge, Minangkabau traditional marriage Baralek Gadang provides general knowledge to the public about their traditional wedding procession. Meanwhile, particularly for the Minangkabau community, the wedding is one of the ancestors' historical legacies whose processions will continue to exist whose customary values in each procession will not be lost. The history contained aims that the community, both in the village and overseas, can understand all forms of past experiences. It can be used as a reference for learning in today's life. In addition, in the Minangkabau traditional wedding procession, value education that can be used as a guide for the life of the Minangkabau community is religious, social, language, artistic, and economic values. The value of education obtained can be implemented in everyday 
life. The values of local wisdom in the traditional Minangkabau Baralek Gadang wedding must be maintained by the community so that the specialty and uniqueness of each Minangkabau traditional wedding procession is not lost due to the influence of outside cultures.

The fourth is the language value. The language value contained in the traditional Minangkabau Baralek Gadang wedding procession is in the signexchange wedding preparation procession where the bride and groom-to-be will give a sign in the form of a valuable object. The language used to communicate in this procession is Minangkabau language, which requires give and reply rhyme or called as sambah menyambah. Sambah menyambah in Minangkabau custom is a form of conveying the intentions and goals of the family of the bride-to-be to propose to the groom-to-be. In this process, the rhymes uttered by the bride's family will be reciprocated by the groom's family. In Minangkabau custom, replying to rhymes (sambah menyambah) is generally an obligation that must be present in traditional events. Ideally, in carrying out an event, the Minangkabau community, which always involves traditional elements, cannot be separated from the procession of replying to the rhyme (sambah menyambah).

The fifth is the art value. The artistic value contained in Minangkabau traditional weddings is in the procession of the wedding to welcome the groom to the bride's house. The artistic value shown in this procession is that the groom paraded together with his extended family to be united or sat down side by side with the bride-to-be. This procession is accompanied by traditional and typical Minangkabau music. Apart from that, the groom-to-be's family is greeted by the youth of pencak silat, who participated in celebrating the welcoming ceremony.

Based on these findings, the local wisdom values found in Minangkabau Baralek Gadang traditional marriage are in line with the opinion of Affandy (2019). It is said that local wisdom is a wealth of local culture that contains meaning as a virtue and view of people's lives to implement these cultural values in daily life. The cultural values in Minangkabau Baralek Gadang traditional marriage contain values consisting of religious values, social values, knowledge values, language values, and art values. These five values found are a form of view of Minangkabau people's life in implementing in daily life, especially in household life.

The relevant things that Rasyidin in Makmur and Dastina (2018) has identified local wisdom in an ethnicity consisting of local wisdom in the form of philosophy; local wisdom in the form of social attitudes, and suggestions expressed in the form of proverbs, parables, poems or folklore; local wisdom in the form of traditional ceremonies; local wisdom in the form of real principles, norms, and rules in the social system; and local wisdom in the form of daily habits and behaviors in social interactions. The opinion is relevant to this research that the local wisdom obtained through the traditional marriage of Minangkabau Baralek Gadang comes from local wisdom in the form of traditional ceremonies. Minangkabau traditional weddings, as shown above, are very viscous and sacred with traditional ceremonial processions consisting of pre-wedding processions, wedding processions, and after-wedding processions. Local wisdom obtained is a form of development of the Minangkabau community identity to maintain the culture for generations.

\section{CONCLUSIONS}

Marriage in the life of the Minangkabau community is a transitional period in order to form a new family. For Minang men, marriage is a process of entering into a new environment, namely the family of his wife. Meanwhile, for women, marriage is a process of adding new members to the rumah gadang. The wedding procession in the Minangkabau indigenous community is called a Baralek Gadang (big party), which consists of a procession for wedding preparation, the implementation of the wedding, and after the wedding. The procession of the wedding stages in the Minangkabau tradition contains local wisdom values, namely religious values, social values, knowledge values, language values, and artistic values. The values of local wisdom in every traditional Minangkabau wedding procession have been around for a long time and through a long journey of time and throughout the community's existence. The existing local wisdom values need to be preserved, maintained, and preserved by the next generation to achieve the Minangkabau community's progress.

The research's limitations are focusing on an in-depth analysis of Minangkabau traditional marriage and not conducting field research related to Minangkabau customary marriage. Meanwhile, the implications of the findings and results of the analysis in the research give readers a perspective on the local wisdom values found in Minangkabau traditional marriages. The limitations contained in the research are expected to be considered for researchers and readers to conduct further research on the local wisdom values of Minangkabau culture, especially related to traditional marriage.

\section{REFERENCES}

Affandy, S. (2019). Penanaman nilai-nilai kearifan lokal dalam meningkatkan perilaku keberagaman peserta didik. Atthulab: Islamic Religion Teaching and Learning Journal, 2(2), 69-93. https://doi. org/10.15575/ath.v2i2.3391.

Alif, M. (2016). Komunikasi antar budaya dalam pernikahan adat Minangkabau di kota Banjarbaru. Metacommunication: Journal of Communication studies, 1(1), 1-19. https://doi.org/10.20527/ mc.v1i1.4670. 
Alma, B. (2010). Pembelajaran studi sosial. Bandung: Alfabeta.

Amir, M. (2011). Adat Minangkabau pola dan tujuan hidup orang Minang. Jakarta: Mutiara Sumber Widya.

Ardillah, N. (2019). Communication activities in maresek to prepare the wedding customs of the Minang (Ethnography of communication tradition of indigenous maresek Minang Bukittinggi nagari Salo). JOM FISIP, 6, 1-14.

Asmaniar, A. (2018). Perkawinan adat Minangkabau. Binamulia Hukum, 7(2), 131-140. https://doi. org/10.37893/jbh.v7i2.23.

Elia, S. (2016). Pemaknaan prosesi baralek nagari Padang (Studi etnografi komunikasi pada masyarakat Minangkabau kota Padang, Sumatera Barat (Thesis). Tangerang: Universitas Multimedia Nusantara.

Firdaus, D. R. S., Djuara, L., Susanto, D., \& Soetarto, E. (2018). Potrait of the Minangkabau culture according to Hofstede's six cultural dimensions. Sodality: Jurnal Sosiologi Pedesaan, 6(2), 121-130. https://doi.org/10.46937/18202030330.

Gustin, N. Y., Baidar., \& Elida. (2016). Makna juadah pada acara manjalang mintuo di nagari Lubuk Pandan kabupaten Padang Pariaman. Home Economic and Tourism, 12(2), 1-25.

Hastuti, E., \& Oswari, T. (2016). Budaya pernikahan masyarakat Minang rantau di Jakarta. UG Jurnal, 10(8), 1-11.

Hati, P. C. (2018). Dakwah pada masyarakat Minangkabau (Studi kasus pada kaum Padri). Islamic Communication Journal, 3(1), 105-120. https://doi. org/10.21580/icj.2018.3.1.2681.

Janosik, S. M. (2005). Adat dan upacara perkawinan daerah Sumatera Barat. NASPA Journal, 42(4), 32-40. https://doi.org/10.1017/CBO9781107415324.004.

Koentjaraningrat. (1990). Kebudayaan mentalitas dan pembangunan. Jakarta: Gramedia Pustaka Utama.

Krippendorff, K. (2013). Content analysis an introduction to its methodology (2n Ed.). California: Sage Publications, Inc.

Makmur, T., \& Dastina, W. (2018). Cultivating local wisdom in character education: Lessons from family education values of Indonesian traditional ceremony.
Walisongo: Jurnal Penelitian Sosial Keagamaan, 26(2), 417-444. https://doi.org/10.21580/ ws.26.2.2753.

Navis, A. A. (1984). Alam takambang jadi guru: Adat dan kebudayaan Minangkabau. Jakarta: Grafiti Pers.

Nofiardi. (2018). Perkawinan dan baganyi di Minangkabau: Analisis sosiologis kultural dalam penyelesaian perselisihan. Al-Ihkam Jurnal Hukum \& Pranata Sosial, 13(1), 49-72. https://doi.org/10.19105/alihkam.v13i1.1613.

Putra, D. E., \& Iskandar, D. (2019). Kontruksi makna tradisi adat baralek nagari Payakumbuh. Prosiding Jurnalistik, 5(2), 131-141. https://doi.org//10.29313/. v0i0.17326.

Rahyono. (2009). Kearifan budaya dalam kata. Jakarta: Wedatama Widyasastra.

Sitompul, R. (2017). Perkawinan bajapuik dan konsekwensinya dalam keluarga Minang. JPPUMA: Jurnal Ilmu Pemerintahan Dan Sosial Politik Universitas Medan Area, 5(1), 9-14. https://doi. org/10.31289/jppuma.v5i1.997

Sumardi, A. (2017). Nilai budaya panibo dalam adat perkawinan di Minangkabau. Jurnal Sasindo Unpam, 4(1), 17-25. http://dx.doi.org/10.32493/ sasindo.v4i1.\%25p.

Suwardani, N. P. (2015). Pewarisan nilai-nilai kearifan lokal untuk memproteksi masyarakat Bali dari dampak negatif globalisasi. Journal of Bali Studies, 5(2), 247-264.

Sylvia., Syahrel., \& Marzam. (2014). Struktur penyajian malam bainai pada pesta perkawinan di kota Padang. Sendra Tasik, 2(3), 71-78.

Tanjung, H. T. (2017). Implementasi tata cara perkawinan adat Minangkabau di Sumatera Barat (Studi: di kabupaten Dharmasraya, Padang). Semarang: Universitas Islam Sultan Agung.

Trimilanda, A. S., \& Desriyeni. (2018). Purwarupa ensiklopedi adat perkawinan Minangkabau. Jurnal Ilmu Informasi Perpustakaan Dan Kearsipan, 7(1), 205-212. https://doi.org/10.24036/100978-0934.

Zed, M. (2008). Metode penelitian kepustakaan. Jakarta: Yayasan Obor Indonesia. 